\title{
Karakteristik Endapan Tsunami Berdasarkan Bukti Palinologi dan Sedimentologi di Bagian Timur Pulau Simeulue, Aceh, Indonesia
}

\author{
Winarni1, Anis Kurniasih ${ }^{*}$, Septriono Hari Nugroho², Jenian Marin ${ }^{1}$, Reddy \\ Setyawan 1 , Purna Sulastya Putra ${ }^{3}$ dan Eko Yulianto ${ }^{3}$
}

\author{
'Departemen Teknik Geologi, Fakultas Teknik, Universitas Diponegoro \\ Jl. Prof. H. Soedharto, Tembalang, Semarang, 50275 \\ 2Pusat Penelitian Laut Dalam, Lembaga Ilmu Pengetahuan Indonesia \\ Jl. Y. Syaranamual, Guru-Guru, Poka, Ambon, 97233 \\ 3Pusat Penelitian Geoteknologi, Lembaga Ilmu Pengetahuan Indonesia \\ Kompleks LIPI, Jalan Sangkuriang, Bandung, 40135 \\ Email: aniskurniasihgeo@gmail.com
}

\section{Abstract \\ Characteristic of Tsunami Deposit Based on Palynology and Sedimentology Records from Eastern Part of Simeulue Island, Aceh, Indonesia}

Simeulve Island was located in an active tectonic zone that causes earthquakes followed by tsunamis. This research was conducted to get a detail explanation of tsunami deposits found in eastern Simeulve Island. The methods used in this study include granulometry analysis, Loss on Ignition (LOI), X-ray Fluorescence (XRF), and palynology. Based on analyzed, it was known that tsunami deposits in the studied area have non-uniform grain size characteristics and are dominated by gravel to boulder. The results of the LOI analysis show that the concentration of organic and carbonate material was very high, which is thought to be caused by a mixture of marine and terrestrial materials due to a tsunami. XRF analysis showed high content of $\mathrm{Ca}$ and $\mathrm{Sr}$ which indicated the influence of seawater on sediments. The palynological analysis showed that taxa from the lowlands and mangroves palynofacies dominate the presence of pollen, indicating that the possibility of depositional environments is the area around the mangrove coast. The presence of high lowland taxa is thought to originate from the tsunami backwash that brought material from the lowlands to the surrounding coast.

Keywords : Tsunami; sediment; palynology; Simeulve Island

\begin{abstract}
Abstrak
Pulau Simeulve terletak pada zona tektonik aktif yang menyebabkan terjadinya banyak gempa yang diikuti tsunami. Penelitian ini bertujuan untuk mengetahui karakteristik detil endapan tsunami yang terdapat di Pulau Simeulue bagian timur. Metode yang digunakan dalam penelitian ini meliputi analisis palinologi, granulometri, Loss on Ignition (LOI), dan XRay Flourescence (XRF). Berdasarkan analisis tersebut diketahui bahwa endapan tsunami di daerah penelitian memiliki karakteristik ukuran butir yang tidak seragam dan didominasi oleh ukuran butir kerikil hingga bongkah. Hasil analisis LOI menunjukkan konsentrasi material organik dan karbonat sangat tinggi, yang diduga disebabkan oleh percampuran material asal laut dan darat karena tsunami. Analisis XRF menunjukkan tingginya kandungan unsur $\mathrm{Ca}$ dan $\mathrm{Sr}$ yang mengindikasikan adanya pengaruh air laut pada endapan. Analisis palinologi menunjukkan taksa dari palinofasies dataran rendah dan mangrove mendominasi kehadiran polen. Hal ini mengindikasikan bahwa kemungkinan lingkungan pengendapan adalah area sekitar pantai mangrove. Kehadiran taksa dataran rendah yang tinggi diduga berasal dari gelombang balik tsunami yang membawa material dari dataran rendah ke sekitar pantai tersebut.
\end{abstract}

Kata kunci : Tsunami; sedimen; palinologi; Simeuleu 


\section{PENDAHULUAN}

Wilayah daratan Simeulue secara geografis terletak di sebelah barat Provinsi Aceh dengan jarak 105 mil laut dari Meulaboh Kabupaten Aceh Barat atau 85 mil laut dari Tapak Tuan Kabupaten Aceh Selatan. Pulau Simeulve merupakan bagian dari jajaran tinggian depan busur (forearc high) yang memanjang di sepanjang baratdaya Pulau Sumatera (Mccaffrey, 2008). Tinggian ini terbentuk sebagai hasil dari aktivitas tumbukan Lempeng Samudera Hindia dan Lempeng Benua Eurasia.

Gempa dan tsunami yang terjadi pada 26 Desember 2004 yang melanda Aceh, diketahui juga melanda wilayah SImeulue. Selain itu, terbukti pula bahwa daerah ini terdampak tsunami akibat gempa pada 28 Maret 2005 dilihat dari adanya jejak penggenangan atau inundasi akibat tsunami hingga sejauh $80 \mathrm{~m}$ dari pantai. Akibat gempa ini pula, beberapa bagian pulau mengalami pengangkatan (uplift) $1-4 \mathrm{~m}$ dan di bagian lain pulau terjadi penenggelaman (subsidence) $1 \mathrm{~m}$ (Borrero et al., 2011 ; Briggs et al., 2006).

Penelitian ini dilakukan pada sampel pengeboran inti sedimen di salah satu area dekat pantai di bagian timur-tenggara Pulau Simeulve. Tujuan penelitian adalah menyelidiki hubungan antara kelimpahan palinomorf dan mekanisme pengendapan sedimen dan menentukan keterlibatan tsunami dalam proses pengendapan.

Penelitian sebelumnya tentang identifikasi endapan tsunami menggunakan data palinologi belum banyak dilakukan, terutama di Indonesia. Adapun salah satu penelitian yang menggunakan data palinologi untuk mengidentifikasi endapan tsunami dilakukan oleh Grand Pre et al. (2012). Penelitian tersebut dilakukan di sekitar Banda Aceh menggunakan data mikro dan makrofosil, salah satu diantaranya adalah data polen. Hasil penelitian tersebut menunjukkan bahwa paleosoil yang terbentuk oleh akibat aktivitas seismik laut seperti tsunami ditemukan secara konsisten banyak mengandung polen dari taksa mangrove. Perbedaan penelitian oleh Grand
Pre et al. (2012) dengan penelitian ini selain dari lokasinya yaitu penelitian ini tidak hanya menggunakan data palinologi namun juga menggunakan metode analisis granulometri, Loss on Ignition (LOI), dan analisis X-Ray Flourescence (XRF).

\section{MATERI DAN METODE}

Penelitian ini merupakan bagian dari Ekspedisi Widya Nusantara Tahun 2017 yang diselenggarakan oleh Pusat Penelitian Oseanografi, LIPI. Pengambilan data lapangan diawali dengan observasi morfologi sepanjang pesisir pantai untuk menentukan lokasi titik pengambilan sampel sedimen. Lokasi yang dipilih adalah daerah yang memiliki relief datar atau agak cekung dan terhalang dari arus laut saat ini. Lokasi pengambilan data lapangan pada penelitian ini berada di bagian timur Pulau Simeulve, berjarak sekitar 300 meter dari garis pantai terdekat (Gambar 1).

Pengambilan sampel sedimen dilakukan dengan teknik coring tumbuk secara vertikal pada lapisan sedimen menggunakan pipa pvc yang dipukul dengan alat tumbuk yang telah dimodifikasi. Setelah itu, pipa ditarik ke permukaan dan sampel dideskripsi secara megaskopis. Berdasarkan deskripsi, diidentifikasi keterdapatan endapan kandidat tsunami. Setelah diketahui adanya endapan kandidat tsunami, sampel dikirim ke laboratorium untuk dilakukan analisis secara lebih menyeluruh.

Analisis laboratorium seluruhnya dilakukan di Laboratorium Sedimentologi, Pusat Penelitian Geoteknologi, LIPI Bandung. Sampel merupakan hasil pengeboran inti sedimen dengan kedalaman $41 \mathrm{~cm}$. Sampel dianalisis dengan interval $1 \mathrm{~cm}$.

Analisis granulometri bertujuan untuk mengetahui sebaran ukuran butir pada sampel sedimen. Analisis granulometri penting dilakukan karena dapat menggambarkan mekanisme pengangkutan dan pengendapan material sedimen ( $\mathrm{C}-\mathrm{M}$ Passega, 1964). Analisis dilakukan menggunakan alat Mastersizer 2000 yang dapat menganalisis butiran berukuran pasir (2 $\mathrm{mm}$ ) hingga 0,02 $\mu \mathrm{m}$. Selanjutnya diolah menggunakan perangkat lunak gradistat 
untuk mengetahui persentase ukuran butir, mean (rata-rata), standar deviasi (sortasi), skewness, dan kurtosis (Blott dan Pye, 2001). Klasifikasi ukuran butir yang digunakan adalah Folk dan Ward (1957).

Analisis LOI bertujuan untuk mengetahui perbandingan jumlah material organik dan karbonat dalam sampel sedimen. Metode analisis LOI mengikuti prosedur yang dilakukan oleh Heiri et al. (2001). Untuk mengetahui persentase material organic dalam sampel, yakni sampel dipanaskan hingga $550^{\circ} \mathrm{C}$ kemudian ditimbang dan beratnya dibandingkan dengan berat sampel sebelum dipanaskan. Setelah itu sampel kembali dipanaskan hingga $950^{\circ} \mathrm{C}$, berat sebelum dan setelah pembakaran digunakan dalam kalkulasi untuk menghitung kadar karbonat.

Analisis XRF bertujuan untuk mengetahui komposisi kimia beserta konsentrasi unsur-unsur kimia dalam sampel. Analisis dilakukan dengan memasukkan sampel pada plastik tipis dan kemudian ditempatkan pada alat handheld portable
XRF dengan tanpa menghancurkan sampel terlebih dahulu (non-destructive analysis). Interpretasi asal dari keberadaan unsur kimia penciri mengacu pada penelitian oleh Chagué-Goff et al. (2017).

Analisis palinologi bertujuan untuk mengetahui keterdapatan dan kelimpahan palinomorf dalam sampel. Palinomorf yang dimaksud meliputi polen, spora, dan dynocyst. Kelimpahan polen dan spora berguna untuk mengetahui kondisi ekologi suatu lingkungan pada saat polen dan spora tersebut terendapkan bersama dengan material sedimen lainnya.

Analisis ini meliputi tahapan preparasi, determinasi jenis palinomorf (terutama polen dan spora), dan penghitungan populasi tiap takson. Preparasi polen dan spora dilakukan dengan metode asetolisis standar (Faegri dan Iversen, 1989) yang menggunakan larutan asetosisis berupa campuran Asam Ahhydrid $\left(\mathrm{C}_{4} \mathrm{H}_{6} \mathrm{O}_{3}\right)$ dan Asam Sulfat $\left(\mathrm{H}_{2} \mathrm{SO}_{4}\right)$. Identifikasi menggunakan katalog polen dan spora Erdtman (1952), Poliakova dan Behling (2016), koleksi referensi dari Smithsonian

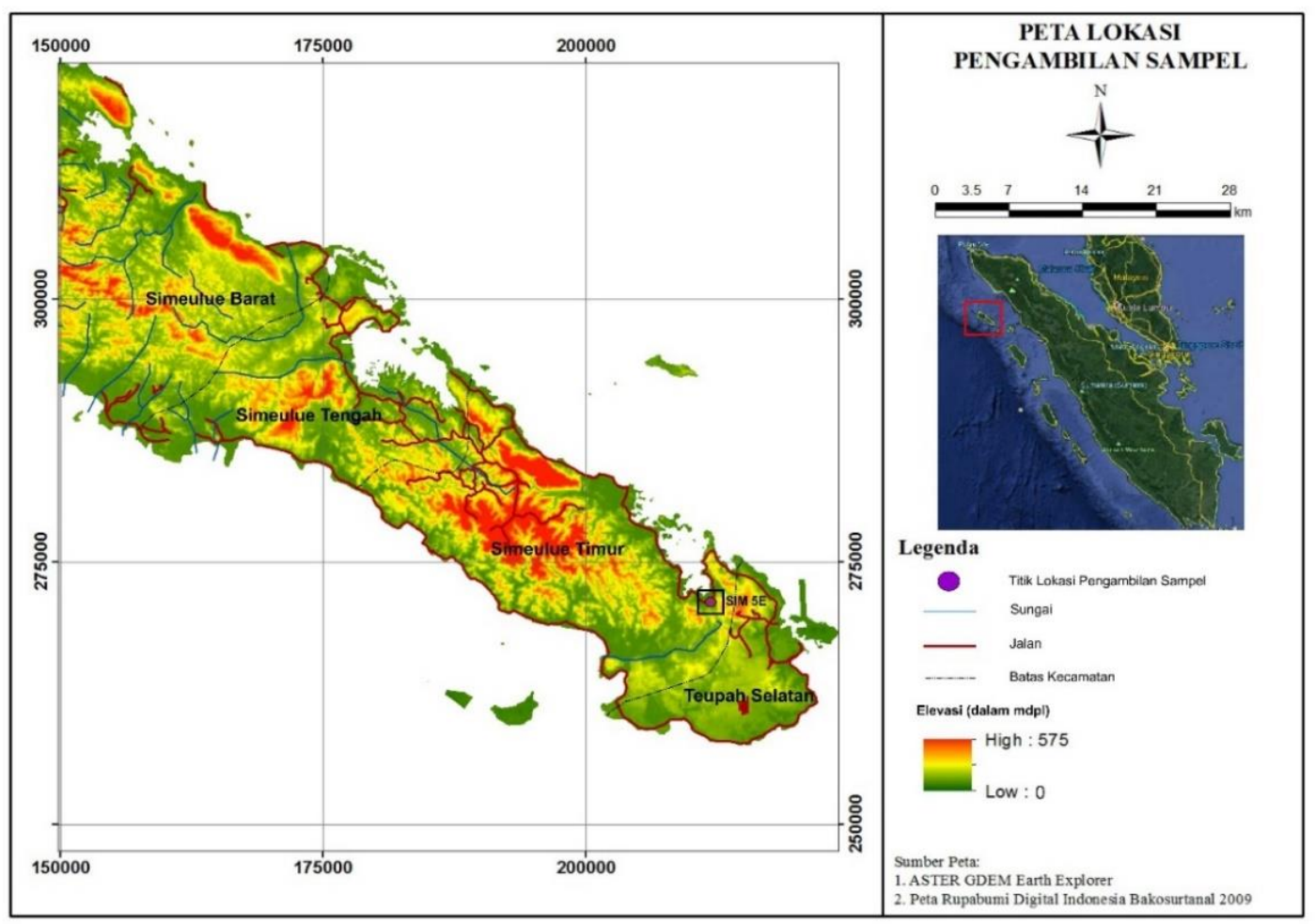

Gambar 1. Lokasi penelitian dan pengambilan sampel 
Tropical Research Institute, dan Australasian Pollen and Spore Atlas. Berdasarkan hasil identifikasi maka selanjutnya dapat diketahui habitus tumbuhan penghasil polen dan sporanya secara kuantitatif. Data tersebut diolah menggunakan perangkat lunak PAST (Paleontological Statistics) ver. 3.0 dan XLSTAT. Diagram palinologi disajikan menggunakan program C2.

\section{HASIL DAN PEMBAHASAN}

Sampel diambil di lokasi yang berjarak kurang lebih 300 meter dari garis pantai. Secara megaskopis (Gambar 2), bagian atas sampel pada kedalaman $0-21 \mathrm{~cm}$ tersusun oleh sedimen berukuran butir sangat halus (lanau - lempung) dan banyak terdapat fragmen akar tumbuhan. Lapisan sedimen ini berwarna abu-abu kecokelatan dan di beberapa bagian berwarna cokelat kemerahan. Di bagian bawah (kedalaman $22-41 \mathrm{~cm}$ ) lapisan sedimen berukuran butir sangat kontras dengan lapisan di atasnya. Lapisan ini tersusun oleh bongkah-bongkah besar pecahan karang yang bercampur dengan lumpur berwarna hitam. Berdasarkan kenampakan tersebut maka lapisan pada interval kedalaman ini diidentifikasi sebagai lapisan kandidat endapan tsunami.

Analisis granulometri pada 41 sampel sedimen menunjukkan hasil seperti terlihat pada Gambar 3. Lapisan di kedalaman 0-21 $\mathrm{cm}$ menunjukkan hasil analisis yang berbeda dari lapisan di bawahnya. Kurva yang terbentuk adalah kurva unimodal yang berarti lapisan ini didominasi oleh satu jenis ukuran butir. Nilai rata-rata (mean) berkisar 5,094-6-997 $\$$ yang termasuk dalam ukuran butir lanau kasar hingga lanau sedang. Sortasi buruk hingga sangat buruk dengan nilai $1,651-2,118 \quad \phi$. Skewness atau kemencengan berkisar antara $-0,115-0,095 \phi$ yang menunjukkan tipe coarse skewed dan kurtosis berkisar antara 1,031-1,221 $\phi$

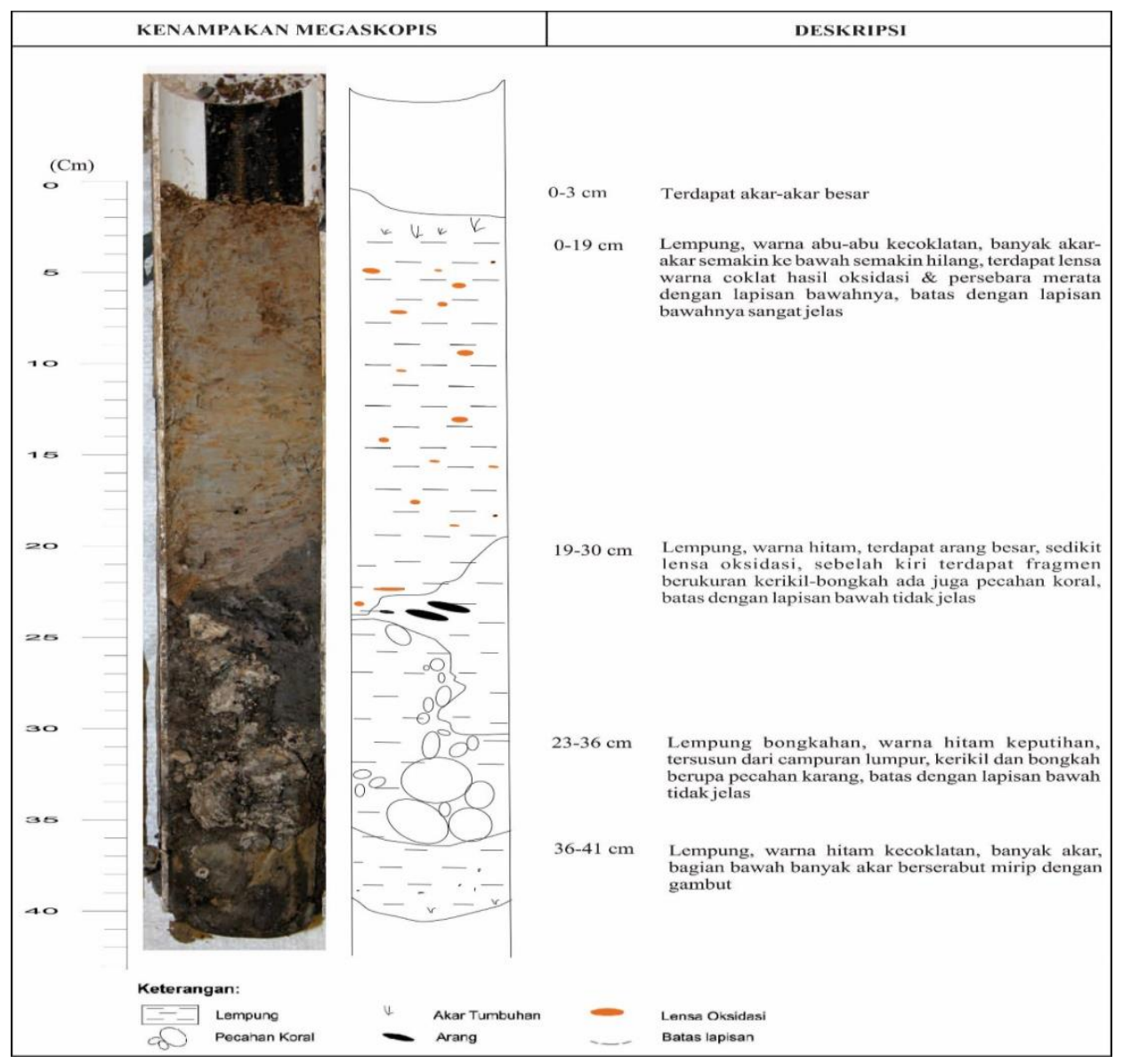

Gambar 2. Kenampakan sampel secara megaskopis dan hasil deskripsi di lapangan, lapisan kandidat endapan tsunami diperkirakan berada pada interval kedalaman $22-41 \mathrm{~cm}$ 
yang menunjukkan tipe mesokurtik dan leptokurtik.

Pada kedalaman 22-41 cm terdapat material berukuran kerikil hingga bongkah sebagai fragmen dan matriks berukuran lebih halus. Berdasarkan analisis granulometri pada matriks sedimen tersebut, memiliki kurva bimodal yang berarti bahwa terdapat dua ukuran butir yang mendominasi. Nilai mean berkisar antara 5,114-6,503 $\phi$ yang menunjukkan ukuran butir lanau kasar hingga lanau sedang dan sortasi buruk hingga sangat buruk dengan nilai 1,651-2,383 $\phi$. Nilai skewness berkisar antara $-0,125-0,016 \phi$ yang termasuk dalam tipe coarse skewed dan kurtosis 0,933-1,105 $\phi$ yang termasuk dalam tipe mesokurtik.
Pada Gambar 4 dapat diamati bahwa sampel sedimen dari kedalaman $22-41 \mathrm{~cm}$ yang memiliki sortasi sangat buruk dengan dominasi material berukuran butir lanau dan bongkah, memiliki mekanisme transportasi sedimen berupa suspension hingga rolling and ground suspension. Proses rolling dan ground suspension terjadi akibat arus berenergi tinggi yang mengangkut ukuran butir kasar melalui mekanisme bedload. Sementara itu, pada kedalaman $0-21 \mathrm{~cm}$, seluruh sampel mengindikasikan adanya proses pengendapan secara suspensi. Sehingga diinterpretasikan arus yang mengendapkannya memiliki energi rendah.

Hasil analisis LOI ditampilkan dalam grafik pada Gambar 5. Pada gambar

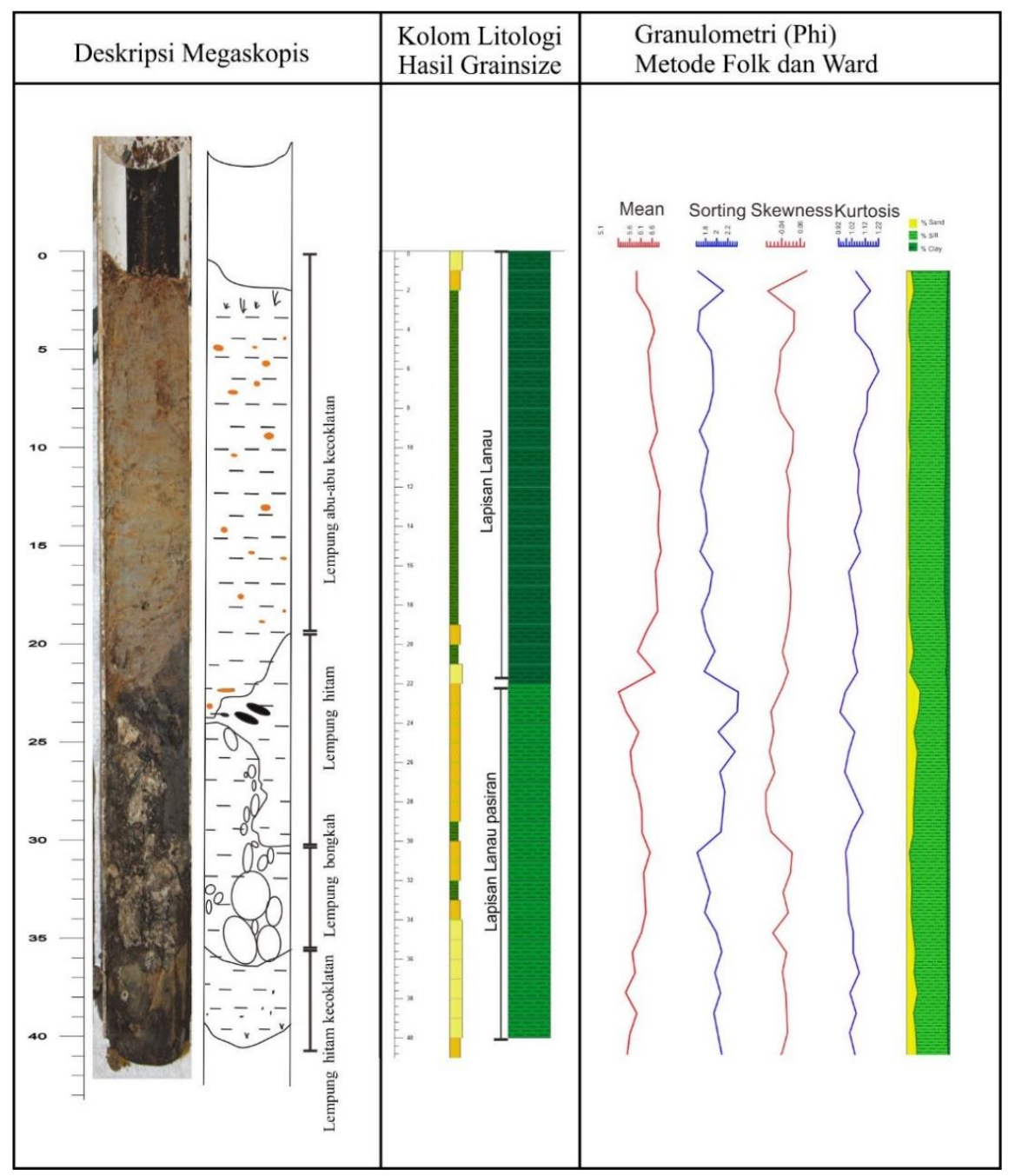

Gambar 3. Grafik hasil analisis granulometri, warna hijau pada kolom menunjukkan ukuran butir lanau-lempung sedangkan warna kuning menunjukkan ukuran butir pasir. 
tersebut dapat diamati di kedalaman $22-41$ antara $17-32 \%$ dengan rata-rata $24 \%$. Tingginya kandungan material organik ini juga diikuti dengan kandungan material karbonat yang tinggi dengan rata-rata $45 \%$. Sementara itu pada kedalaman $0-21 \mathrm{~cm}$ terjadi penurunan kadar organik dan karbonat secara drastis. Kadar material organik sekitar $12 \%$ - 19\% dengan rata-rata $14 \%$ dan material karbonat rata-rata sekitar $26 \%$.

Analisis XRF bertujuan untuk mengetahui kandungan unsur kimia pada sampel. Unsur kimia tersebut meliputi $\mathrm{Zr}, \mathrm{Fe}, \mathrm{K}$, $\mathrm{Sr}, \mathrm{Rb}, \mathrm{Ti}, \mathrm{Zn}, \mathrm{Mn}$, dan Ca yang dinyatakan dalam satuan ppm (part per million). Hasil analisis XRF pada 41 sampel ditampilkan dalam grafik pada Gambar 6. Nilai rata-rata kandungan masing-masing unsur kimia ditampilkan dalam Tabel 1.

Pada kedalaman 22-41 cm, kandungan unsur $\mathrm{Sr}$ dan $\mathrm{Ca}$ cenderung tinggi. Unsur Sr memiliki rata-rata 404,18 ppm dan unsur Ca 27766,15 ppm. Sementara itu, pada kedalaman 0-21 cm, kandungan unsur $\mathrm{Sr}$ dan Ca mengalami penurunan yang jelas. Unsur $\mathrm{Sr}$ memiliki rata-rata 58,86 ppm dan unsur memiliki rata-rata 4660,36 ppm.

Pada penelitian ini diperoleh hasil berupa jumlah polen dan spora yang berkisar antara 257-300 individu pada tiap sampel. Selain itu ditemukan pula dynocyst yang merupakan golongan taksa laut sebanyak 13 individu yang tersebar pada sampel-sampel di kedalaman 22-41 cm. Perbandingan kelimpahan polen, spora, dan dynocyst pada seluruh sampel ditampilkan dalam grafik di bawah ini (Gambar 7).

Dari grafik dapat diamati pada kedalaman $22-41 \mathrm{~cm}$, taksa dari palinofasies dataran rendah dan mangrove mendominasi kehadiran polen. Pada interval kedalaman ini, taksa lingkungan dataran rendah memiliki rata-rata kelimpahan sebanyak 51,3\%. Famili yang paling melimpah yaitu dari famili Euphorbiaceae, Arecaceae, dan Leguminosae. Taksa mangrove memiliki kelimpahan terbanyak kedua yakni rata-rata $32,8 \%$ diantaranya yang paling melimpah adalah Avicennia, Rhizopora sp., Sonneratia alba, dan Malvaceae indet. Selanjutnya taksa grassland memiliki kelimpahan rata-rata sebanyak $9,9 \%$. Taksa yang paling melimpah dari kelompok grassland adalah famili Cyperaceae dan Graminae. Taksa pegunungan merupakan kelompok yang paling sedikit hadir pada interval ini, yakni dengan rata-rata persentase sebanyak $6 \%$, didominasi oleh kehadiran Podocarpus dan Castanopsis sp.

Pada interval kedalaman $1-21 \mathrm{~cm}$, terjadi perubahan pola kelimpahan polen yang ditandai dengan kenaikan persentase kehadiran polen dari taksa grassland dan dataran rendah setelah sebelumnya menurun drastis pada sampel kedalaman 22 $\mathrm{cm}$. Selain itu, kelimpahan polen dari taksa mangrove menurun secara signifikan. Pada interval ini, taksa dataran rendah memiliki kelimpahan rata-rata sebanyak $64,3 \%$ yang didominasi oleh kehadiran polen dari famili Euphorbiaceae, Arecaceae, Oleaceae, dan Moaceae. Selanjutnya taksa grassland memiliki kelimpahan rata-rata sebanyak $26,8 \%$. Taksa dari golongan ini mengalami kenaikan persentase kelimpahan yang signifikan dibandingkan dengan interval di bawahnya. Taksa yang paling melimpah adalah dari famili Cyperaceae dan Gramineae. Sementara itu, kelimpahan taksa pegunungan hanya sekitar 3\%, yang diwakili oleh kehadiran Podocarpus dan Fabaceae indet.

Berdasarkan hasil analisis tersebut di atas maka seluruh sampel pada penelitian ini dikelompokkan menjadi 2 fasies. Pengelompokan ini bertujuan untuk memudahkan dalam menginterpretasi proses pengendapan yang terjadi.

Fasies 1 berada pada interval kedalaman 22-41 cm. Secara megaskopis, lapisan ini ditentukan sebagai lapisan kandidat tsunami dengan ciri-ciri tersusun dari material sangat kasar berukuran kerikil hingga bongkah yang bercampur dengan material halus berukuran lanau-lempung. Material penyusunnya berasal dari pecahan karang dan cangkang serta banyak terdapat fragmen-fragmen tumbuhan seperti arang dan akar. Hasil analisis granulometri menunjukkan adanya dominasi dua ukuran butir yang berbeda dan sortasi yang buruk hingga sangat buruk. 


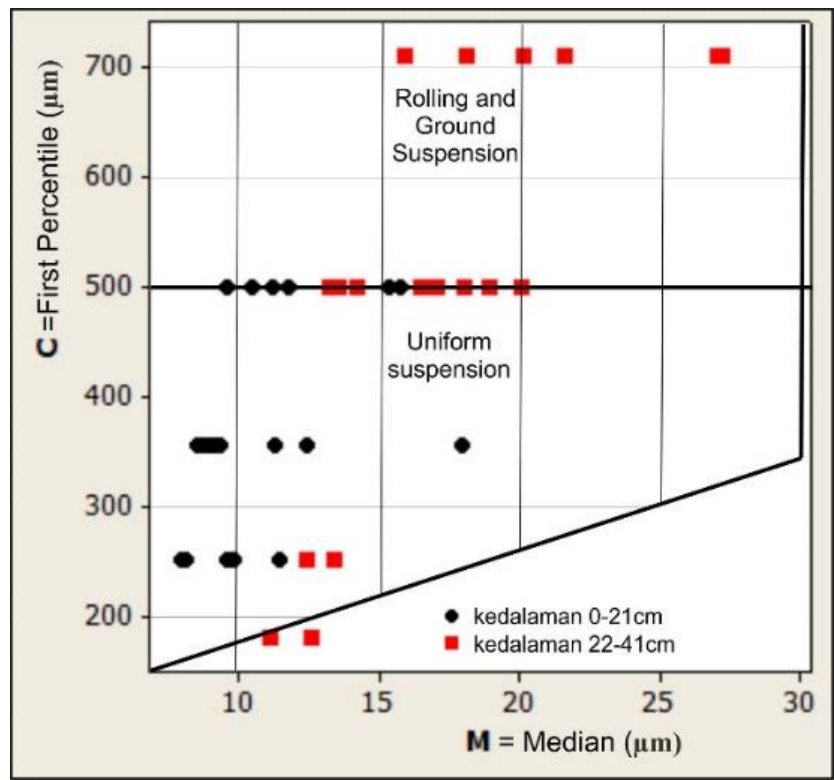

Gambar 4. Diagram C-M yang menggambarkan mekanisme pengendapan butiran sedimen pada masing-masing sampel.

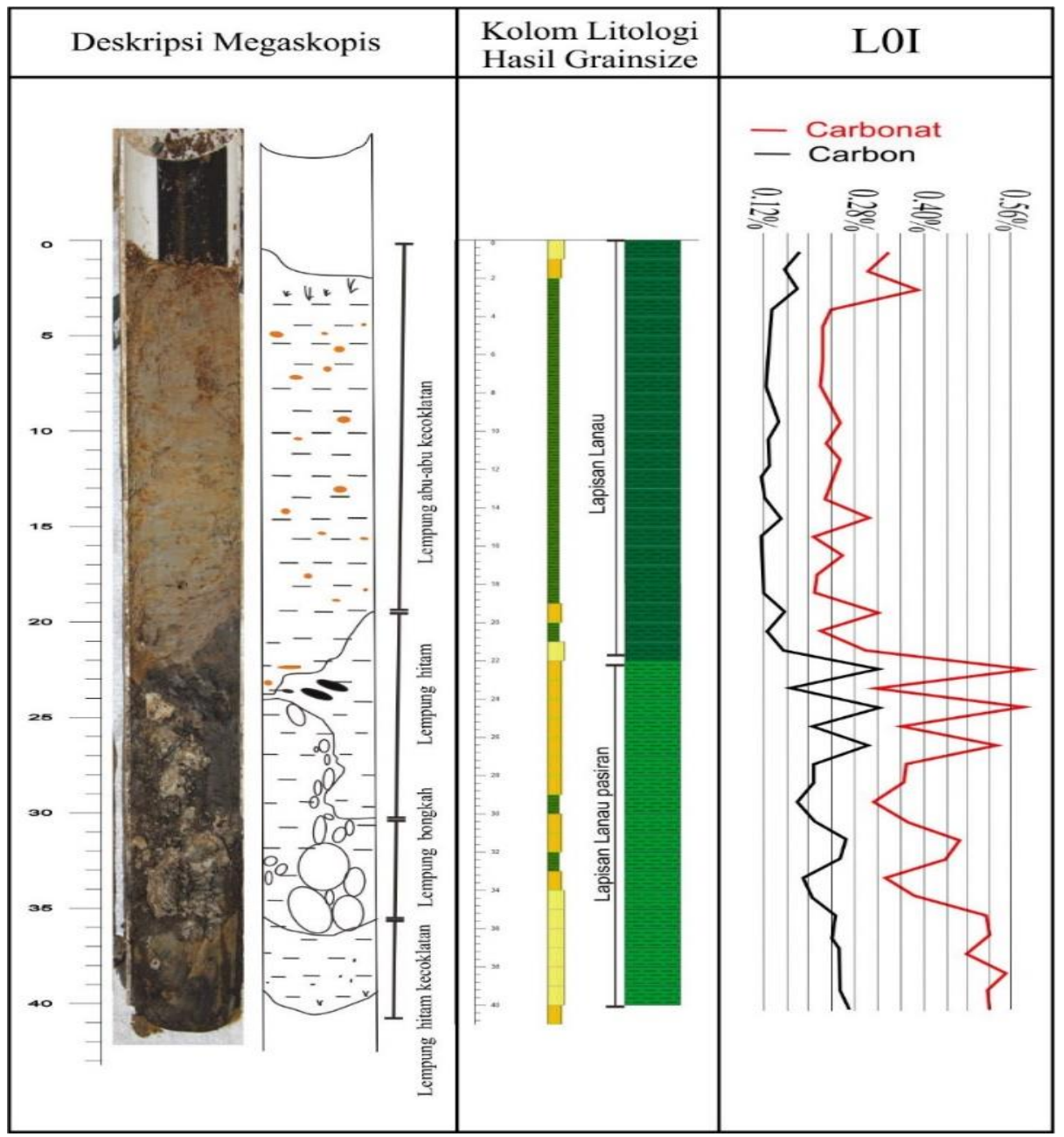

Gambar 5. Grafik fluktuasi kandungan material organik dan karbonat berdasarkan hasil analisis LOI 


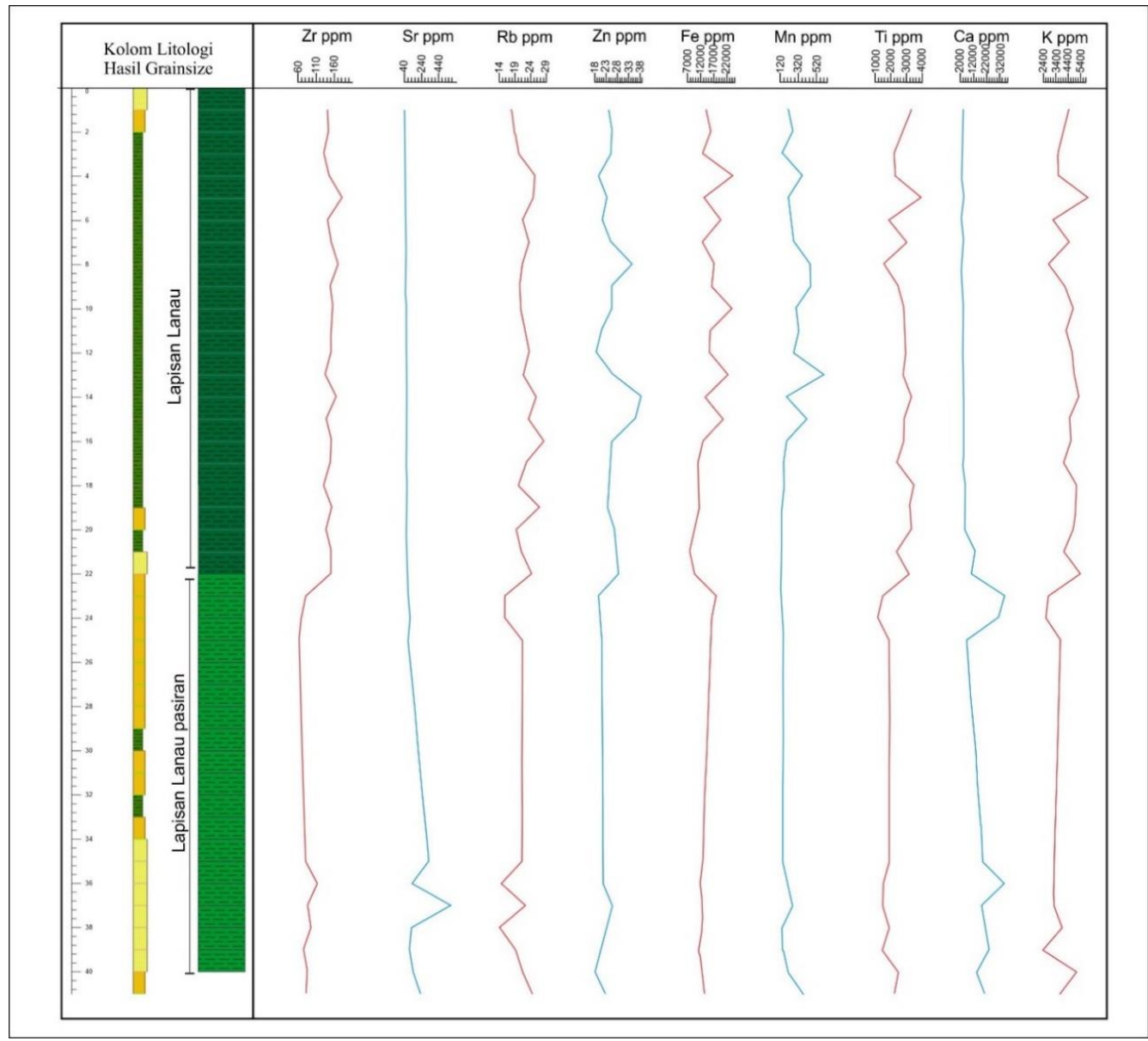

Gambar 6. Grafik hasil analisis XRF yang menunjukkan fluktuasi kandungan unsur kimia $\mathrm{Zr}, \mathrm{Fe}, \mathrm{K}, \mathrm{Sr}$, $\mathrm{Rb}, \mathrm{Ti}, \mathrm{Zn}, \mathrm{Mn}$, dan Ca pada seluruh sampel.

Tabel 1. Nilai rata-rata kandungan unsur kimia (dalam satuan ppm) pada dua lapisan dengan interval kedalaman 0-21 cm dan $22-41 \mathrm{~cm}$.

\begin{tabular}{lrrr}
\hline \multicolumn{2}{c}{ Kedalaman lapisan $(\mathrm{cm})$} & \multicolumn{2}{c}{$0-21$} \\
\hline Nilai rata-rata kandungan & $\mathrm{Zr}$ & 149,42 & 95,51 \\
unsur kimia (ppm) & $\mathrm{Sr}$ & 58,86 & 404,18 \\
& $\mathrm{Rb}$ & 22,34 & 21,26 \\
& $\mathrm{Zn}$ & 26,02 & 29,55 \\
& $\mathrm{Fe}$ & 15360,81 & 15080,26 \\
& $\mathrm{Mn}$ & 275,6 & 197,57 \\
& $\mathrm{Ti}$ & 2791,02 & 4839,38 \\
& $\mathrm{Ca}$ & 4660,36 & 27766,15 \\
& $\mathrm{~K}$ & 4400,66 & 3729,11 \\
\hline
\end{tabular}

Mekanisme pengendapan yang membentuk endapan ini diinterpretasikan sebagai proses rolling and ground suspension. Berdasarkan ukuran butirnya (kerikil hingga bongkah) diinterpretasikan bahwa arus yang membawa material ini memiliki energi cukup tinggi hingga dapat mengangkut sedimen berukuran besar dari laut ke daerah transisi. 
Mekanisme transportasi yang memungkinkan terjadinya proses tersebut antara lain adalah badai dan tsunami. Menurut Dawson et al. (1996), hidrodinamisme tsunami sangat komplek karena pada saat berlangsung tsunami energi arus mengalami perubahan yang sangat drastis dalam jangka waktu singkat. Arus turbulen pada saat gelombang tsunami datang biasanya diikuti dengan perubahan energi yang drastis menjadi lebih tenang pada saat proses inundasi. Setelah itu dapat berubah kembali menjadi turbulen pada saat backwash. Oleh karena itu, parameter ukuran butir saja tidak cukup untuk mengidentifikasi endapan tsunami.

Analisis LOI menunjukkan nilai rata-rata kandungan material organic adalah $24 \%$ dan

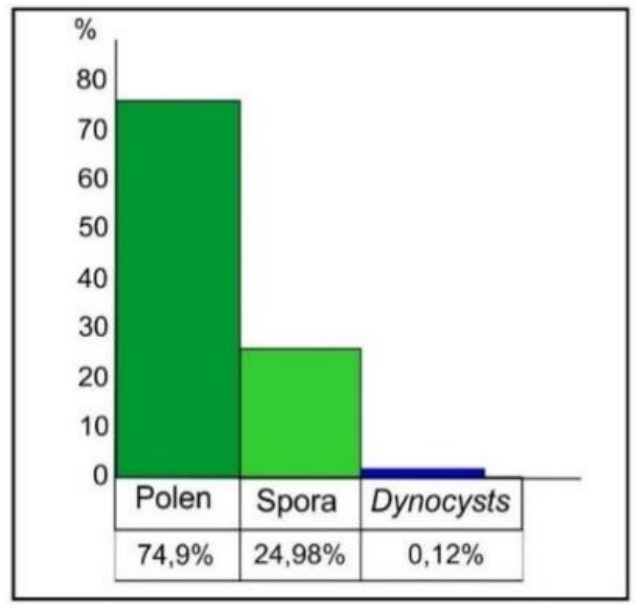

Gambar 7. Grafik perbandingan kelimpahan polen, spora dan dynocyst pada seluruh sampel yang dianalisis

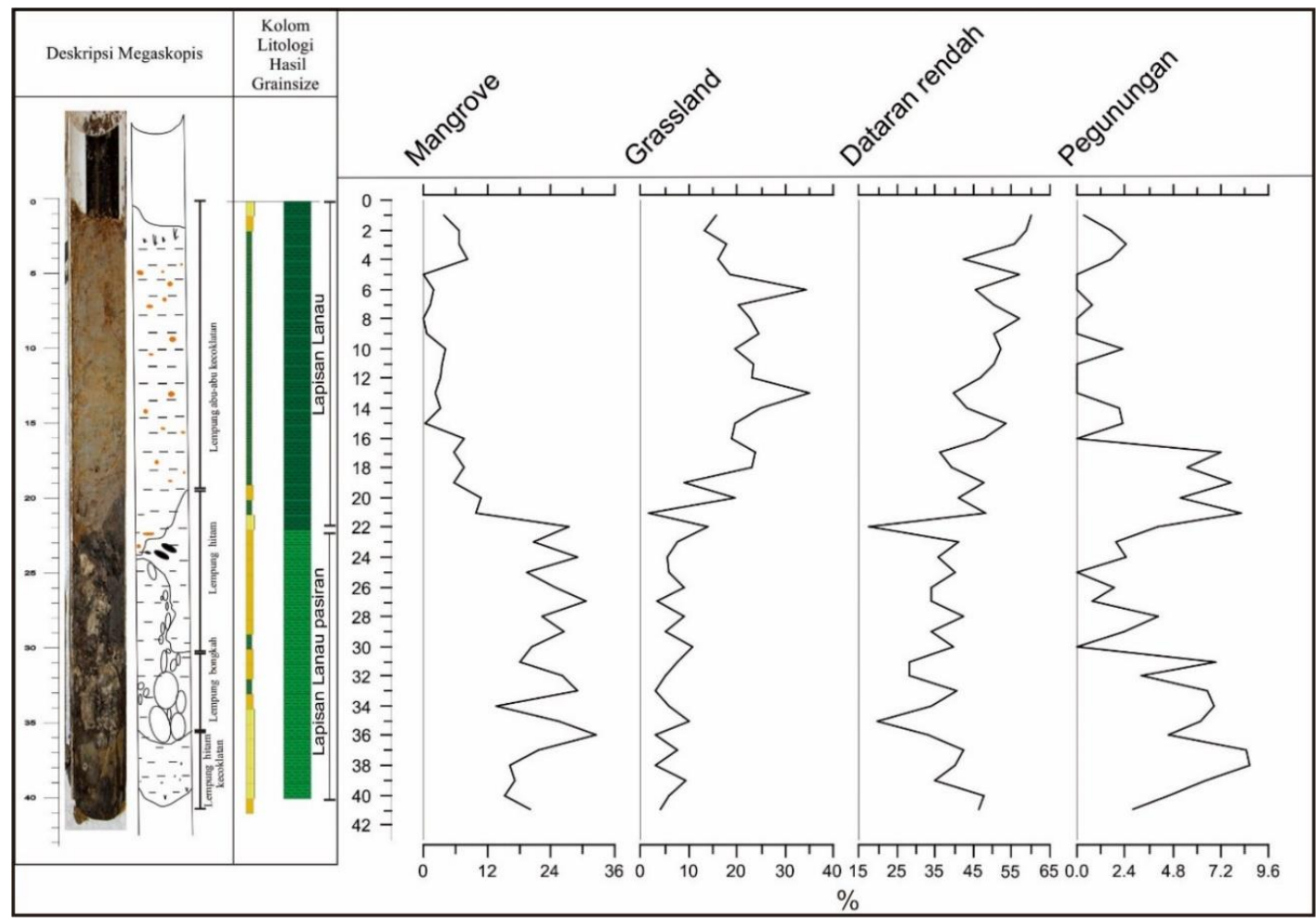

Gambar 8. Grafik persentase kelimpahan total individu polen yang dikelompokkan berdasarkan palinofasiesnya. 
material karbonat sebanyak $45 \%$. Tingginya kadar karbonat pada interval ini disebabkan oleh kehadiran pecahan cangkang dan karang dalam jumlah sangat banyak.

Sementara itu, hasil analisis XRF menunjukkan pada interval ini unsur kimia $\mathrm{Sr}$ memiliki rata-rata 404,18 ppm dan $\mathrm{Ca}$ memiliki kadar 27766,15 ppm. Berdasarkan penelitian yang dilakukan oleh Judd et al. (2017), konsentrasi unsur $\mathrm{Ca}$ dan Sr pada air laut lebih tinggi daripada air tawar. Sehingga tingginya konsentrasi kedua unsur tersebut dalam endapan sedimen mengindikasikan tingginya pengaruh air laut terhadap proses pengendapan sedimen. Tingginya nilai tersebut disebabkan oleh keberadaan pecahan-pecahan cangkang.

Analisis palinologi pada interval kedalaman ini ditandai dengan kehadiran taksa dataran rendah dan mangrove yang sangat mendominasi dibandingkan taksa lainnya. Menurut penelitian yang dilakukan oleh Grand Pre et al. (2012) endapan tsunami di daerah pantai barat Aceh memiliki kelimpahan polen dari taksa mangrove yang bercampur dengan polen percampuran taksa hutan tropis (pegunungan dan dataran rendah). Sehingga jika mengacu pada penelitian tersebut, maka berdasarkan data palinologi diinterpretasikan proses pengendapan lapisan pada interval ini dipengaruhi oleh tsunami.

Tingginya kandungan material organik diduga disebabkan oleh proses tsunami pada saat terjadi backwash (gelombang balik tsunami) yang membawa material dari darat sampai ke lingkungan transisi dan bercampur dengan material asal laut berupa pecahan karang dan cangkang. Hal ini didukung dengan tingginya kehadiran taksa dataran rendah yang menandai gelombang tsunami mencapai lingkungan dataran rendah dan kembali ke laut sambil membawa material dari darat. Fasies 2 berada pada interval kedalaman 0-21 cm. Secara megaskopis, fasies ini memiliki ciri berupa lapisan lempung berwarna abu-abu kecoklatan. Hasil analisis granulometri menunjukkan kurva unimodal yang berarti hanya terdapat satu ukuran butir yang mendominasi yakni lanau kasar hingga lanau sedang. Mekanisme pengangkutan sedimen berdasarkan analisis ukuran butir adalah suspensi.

Analisis LOI menunjukkan rendahnya kadar material organik dan karbonat, ratarata sekitar $14 \%$ dan $26 \%$ secara berurutan. Dibandingkan dengan lapisan di bawahnya persentase kandungan material organik dan karbonat ini mengalami penurunan yang sangat drastis. Hal ini nampak pula pada analisis XRF yang ditandai dengan penurunan kandungan unsur kimia $\mathrm{Sr}$ dan Ca sebagai penunjuk sumber sedimen laut. Hasil analisis palinologi ditandai dengan penurunan kelimpahan taksa mangrove secara drastis dan kenaikan kelimpahan taksa grassland. Selain itu, pada interval ini tidak dijumpai adanya dynocyst sehingga diinterpretasikan pengaruh laut pada pengendapan interval ini tidak setinggi pada interval lapisan di bawahnya.

Berdasarkan analisis tersebut di atas, maka fasies 1 (kedalaman $22-41 \mathrm{~cm}$ ) terbukti merupakan endapan lingkungan transisi yang proses pembentukannya dipengaruhi oleh tsunami. Sedangkan fasies 2 $(0-21 \mathrm{~cm})$ adalah endapan transisi yang mendapat sedikit pengaruh dari laut (tidak dipengaruhi tsunami).

\section{KESIMPULAN}

Berdasarkan hasil analisis yang meliputi analisis Ukuran butir, LOI, XRF, dan palinologi dapat disimpulkan bahwa pada daerah penelitian ditemukan endapan yang terbentuk karena pengaruh proses tsunami yang ditandai dengan ukuran butir yang tidak seragam dan didominasi oleh ukuran butir kerikil hingga bongkah. Material berukuran kasar tersebut merupakan fragmen karang dan pecahan cangkang yang terbawa saat tsunami terjadi. Hasil analisis LOI membuktikan bahwa pada endapan ini memiliki konsentrasi material organik dan karbonat sangat tinggi, yang diduga disebabkan oleh percampuran material asal laut dan darat karena tsunami. Analisis XRF menunjukkan tingginya kandungan unsur $\mathrm{Ca}$ dan $\mathrm{Sr}$ yang mengindikasikan adanya pengaruh air laut pada endapan. Pada endapan non tsunami 
kedua unsur tersebut mengalami penurunan konsentrasi yang signifikan.

Analisis palinologi menunjukkan taksa dari palinofasies dataran rendah dan mangrove mendominasi kehadiran polen. Hal ini mengindikasikan bahwa kemungkinan lingkungan pengendapan adalah area sekitar pantai mangrove. Kehadiran taksa dataran rendah yang tinggi diduga berasal dari gelombang balik tsunami yang membawa material dari dataran rendah ke sekitar pantai tersebut.

Rekomendasi untuk penelitian selanjutnya adalah dilakukan penanggalan umur pada lapisan endapan tsunami untuk mengetahui waktu kejadian tsunami yang membentuk endapan tersebut. Dengan demikian maka dapat diperoleh gambaran proses terjadinya tsunami dengan lebih baik dan rinci.

\section{UCAPAN TERIMA KASIH}

Penelitian ini dibiayai secara parsial oleh Pemerintah Indonesia melalui kegiatan 'flagship' LIPI, Ekspedisi Widya Nusantara Tahun Anggaran 2017.

\section{DAFTAR PUSTAKA}

Australian National University, Australasian Pollen and Spore Atlas, http://apsa.anu. edu.au/. (diakses Mei 2018)

Blott \& Pye, 2001, Gradistat: A Grain Size Distribution and Statistics Package for the Analysis of Unconsolidated Sediments, Earth Surface Processes and Landforms, 26:1237-1248. doi: 10.1002/esp.261

Borrero, J.C., McAdoo, B., Jaffe, B., Dengler, L., Gelfenbaum, G., Higman, B., Hidayat, R., Moore, A., Kongko, W., Lukijanto, Peters, R., Prasetya, G., Trrov, V., and Yulianto, E., 2011, Field Survey of the March 28, 2005 Nias-Simeulue Earthquake and Tsunami, Pure and Applied Geophysics, 168:1075-1088. doi: 10.1007/ s00024-010-0218-6

Briggs, R.W., Sieh, K., Meltzner, A.J., Natawidjaja, D., Galetzka, J., Suwargadi, B., Hsu, Y-J., Simons, M., Hananto, N., Suprihanto, I., Prayudi, D., Avoavac, J-P., Prawirodirdjo, L., Bock, Y., 2006,
Deformation and Slip Along the Sunda Megathrust in the Great 2005 NiasSimeulve Earthquake, Science, 31: 18971901. doi: 10.1126/science.1122602

Chagué-Goff, C., Szczuciński, W. \& Shinozaki, T., 2017, Applications of Geochemistry in Tsunami Research: A Review, EarthScience Reviews, 165:203-244. doi: 10.1016/j.ear scirev.2016.12.003

Dwason, A.G., Shi, S, Dawson, S., Takahashi, T. \& Shuto, N., 1996, Coastal Sedimentation Associated with the June 2nd and 3rd, 1994 Tsunami in Rajegwesi, Java, Quaternary Science Reviews, 15:901-912. doi: 10.1016/S0277-3791 (96)00059-5

Erdtman, G., 1952, Pollen Morphology and Plant Taxonomy - Angiosperms, Almqvist \& Wiksell, Stockholm.

Faegri, K. \& Iversen, J., 1989, Textbook of Pollen Analysis, Hafner Press, New York.

Folk, R.L. \& Ward, W.C., 1957, A Study in the Significance of Grain-Size Parameters, Journal of Sedimentary Petrology, 27:326. doi: 10.1306/74D70646-2B21-11D7-864 8000102 C $1865 D$

Grand Pre, C.A., Horton, B.P., Kelsey, H.M., Rubin, C.M., Hawkes, A.D., Daryono, M.R., Rosenberg, G., \& Culver, S.J., 2012, Stratigraphic Evidence for an Early Holocene Earthquake in Aceh, Indonesia, Quaternary Science Reviews, 54:142-151. Doi: 10.1016/j.quascirev.2012.03.011

Heiri, O., Lotter, F.A. \& Lemcke, G., 2001, Loss on Ignition as a Method for Estimating Organic and Carbonate Content in Sediments: Reproducibility and Comparability of Results, Journal of Paleolimnology, 25:101-110. doi: 10.1023 /A:1008119611481

Judd, K., Chagué-Goff, C., Goff, J., Gadd, P., Zawadzki, A., \& Fierro, D., 2017, Multyproxy Evidence for Small Historical Tsunamis Leaving Little or No Sedimentary Record, Marine Geology, 385:204-215. doi: 10.1016/j.margeo.2017.01.002

Mccaffrey, R., 2008, The tectonic framework of the Sumatran Subduction Zone, The Annual Review of Earth and Planetary Sciences, 37:3.1-3.22. doi: 10.1146/annurev.earth.031208.100212

Passega, R., 1964, Grain Size Representation by CM Patterns as a Geologic Tool, Journal of Sedimentary Research, 34:830- 
847. doi: 10.1306/74D711A4-2B21-11D7$8648000102 \mathrm{C1865D}$

Poliakova, A. \& behling, H., 2016, Pollen and Fern Spores Recorded in Recent and Late Holocene Marine Sediments from the Indian Ocean and Java Sea in Indonesia,
Quaternary International, 392:251-314. doi: 10.1016/j.quaint.2015.06.046

Smithsonian Tropical Research Institute, Pollen Morphology Database, https://stri.si.edu/ research-computing/databases. (diakses Mei 2018) 